\title{
Article \\ Evaluation of the Removal of Organic Matter and Nutrients in the Co-Treatment of Fruit and Vegetable Waste Using a Bioreactor-Constructed Wetlands System
}

\author{
Francisco Orduña-Gaytán ${ }^{1}$ (D), Norma A. Vallejo-Cantú ${ }^{1}$, Andrea Alvarado-Vallejo ${ }^{1}$ (D), \\ Erik Samuel Rosas-Mendoza $^{2}$, , Luis Carlos Sandoval-Herazo ${ }^{3}$ (D) and Alejandro Alvarado-Lassman ${ }^{1, *}(\mathbb{D}$
}

check for updates

Citation: Orduña-Gaytán, F.; Vallejo-Cantú, N.A.;

Alvarado-Vallejo, A.; Rosas-Mendoza,

E.S.; Sandoval-Herazo, L.C.;

Alvarado-Lassman, A. Evaluation of the Removal of Organic Matter and Nutrients in the Co-Treatment of Fruit and Vegetable Waste Using a Bioreactor-Constructed Wetlands

System. Processes 2022, 10, 278.

https://doi.org/10.3390/

pr10020278

Academic Editors: Pietro Bartocci, Qing Yang and Francesco Fantozzi

Received: 27 December 2021

Accepted: 28 January 2022

Published: 30 January 2022

Publisher's Note: MDPI stays neutral with regard to jurisdictional claims in published maps and institutional affiliations.

Copyright: (C) 2022 by the authors. Licensee MDPI, Basel, Switzerland. This article is an open access article distributed under the terms and conditions of the Creative Commons Attribution (CC BY) license (https:// creativecommons.org/licenses/by/ $4.0 /)$.
1 División de Estudios de Posgrado e Investigación, Tecnológico Nacional de México/Instituto Tecnológico de Orizaba, Av. Oriente 9 No. 852 Col. E. Zapata, Orizaba 94320, Mexico; fcoorduna@gmail.com (F.O.-G.); nvallejoc@prodigy.net.mx (N.A.V.-C.); alvaradov.andrea@gmail.com (A.A.-V.)

2 CONACYT-Tecnológico Nacional de México/Instituto Tecnológico de Orizaba, Av. Oriente 9 No. 852 Col. E. Zapata, Orizaba 94320, Mexico; eriksamuelrm@hotmail.com

3 Wetlands and Environmental Sustainability Laboratory, Division of Graduate Studies and Research, Tecnológico Nacional de México/Instituto Tecnológico Superior de Misantla, Veracruz, Km 1.8 Carretera a Loma del Cojolite, Misantla 93821, Mexico; lcsandovalh@gmail.com

* Correspondence: lassman@prodigy.net.mx

\begin{abstract}
This article presents the application of a novel system for the treatment of fruit and vegetable waste (FVW) using the combination of treatment by the application of the liquid fraction to an anaerobic hydrolytic bioreactor and a constructed wetland. The batch-fed anaerobic bioreactor $(\mathrm{AB})$ had an average organic loading rate of $44 \mathrm{~g} \mathrm{COD} / \mathrm{L}-\mathrm{d}$ and a hydraulic residence time (HRT) of $24 \mathrm{~h}$ for the degradation of the liquid fraction of the FVW with an average COD removal of $55 \%$. Subsequently, the constructed wetlands (CWs) were fed a subsurface vertical flow of the effluent from the $\mathrm{AB}$ by stepwise concentration increments from 1 to $12 \mathrm{~g} \mathrm{COD} / \mathrm{L}$ and a HRT $=72 \mathrm{~h}$ until the limit conditions of the operation were identified. For the tropical ornamental species of the CWs in red volcanic gravel (RVG) and RVG + polyethylene (PE) supports, the monoculture of Hippeastrum rutilum and Spathiphyllum wallisii presented removals of COD, Tot-P, and TKN of 90\%, 80\%, and $85 \%$, respectively. The polycultures with both species exceeded $90 \%$ effectiveness. At the end of both processes, a concentration of $\sim 0.5 \mathrm{~g}$ COD/L was achieved, confirming that the use of these technologies together constitutes an efficient system for the treatment of the liquid fraction of FVW.
\end{abstract}

Keywords: bioreactor; anaerobic digestion; fruit and vegetable waste; co-treatment; constructed wetland; ornamental plants

\section{Introduction}

Fruit and vegetable waste (FVW) is an important class of waste because it is produced in considerable quantities in agricultural activities, supermarkets, and local markets [1]. The lack of management of this waste is common in municipalities that have high population densities, which allows the decaying organic matter to facilitate the spread of vectors, diseases, and unpleasant odors and to contaminate the sources of ground and surface waters [2]. This scenario is replicated in countries that do not have adequate wastewater treatment systems [3].

The increase in the generation of municipal solid waste (MSW) has created concern worldwide due to the environmental and economic impacts it produces [4-7] Specifically, organic waste, such as FVW, comprises an important part of this problem because approximately 1750 million tons of this waste is generated annually worldwide [8]. In three North American countries alone (Canada, the United States, and Mexico), it has been estimated that 170 million tons of food waste is generated each year, consisting mainly of FVW (42\%) [9-11]. Despite their negative impacts on the environment, landfills are used 
extensively for the disposal of waste, and they have been banned in some parts of North America. In Canada, however, landfills are still the main disposal route [12,13]. In recent years, there has been a trend toward the use of bioconversion technologies for FVW, which is the case in the United States [14-16]. This is in contrast to Mexico, which, due to its informal disposal or final disposal routes for its extensive agricultural production, produces and disposes of about 20 million tons/year of FVW without any treatment $[9,17,18]$.

Despite the high variability in the composition of FVW, according to Arvanitoyannis and Varzakas [19] its content of readily biodegradable organic matter (75\%) and its high moisture content (80\%) [20] facilitate the biological treatment of this waste, highlighting Anaerobic Digestion (AD) as an efficient and suitable technology for its treatment [21]. However, its weakness in treating elemental pollutants and the limiting stage of hydrolysis make it imperative to use a second alternative technique $[19,22,23]$, such as the implementation of constructed wetlands (CWs), which act as purification systems composed of fixed bed channels and vegetation through which the contaminated water flows. In this process, the reduction of elemental pollutants is achieved by biological and physicochemical means [24].

The hybridization of both methods is due to the efficient treatment that results from the operational advantages of $\mathrm{AD}$ and the use of an engineered, environmentally friendly technology to control pollution and is caused by the lack of effective treatments for mixed fruit and vegetable wastes.

Despite the great importance of the treatment of this type of waste to mitigate adverse environmental impacts, the co-treatment of FVW through the separation of the liquid fraction in hybrid systems has not been studied. The disintegration of the solid particles of FVW causes the release of compounds and increases the specific surface area. Since it provides better contact between the liquid substrate and anaerobic bacteria, it improves the performance in the digestion process. Otherwise, large particles would result in a low degree of COD degradation [25]. This method entails the use of the liquid fraction and obtains benefits by minimizing the loss of biodegradable matter and nutrients that can cause negative environmental impacts. Some authors have reported that anaerobic co-digestion of FVW can be done by combining the organic fraction of municipal solid waste (OFMSW) [1], sewage sludge [26,27], and cow dung [28,29], thereby achieving COD removal efficiencies of up to $90 \%$ in some cases [2] with short operation periods $(24 \mathrm{~h})$ and different bioreactor configurations. Currently, scientific research has developed technologies using biofilms, fluidized bed reactors [30-32], and membrane reactors [33,34] as the only purification pathways, but these approaches present complications in the purification of complex organic material [35].

To the best of our knowledge, there are no works in which constructed wetlands have been used to treat FVW; however, there are new trends in the treatment of domestic and industrial wastewater by evaluating the behavior of tropical ornamental species. Good results have been achieved for the absorption and degradation of components in polluted river effluents, and improvements of up to $7 \%, 16 \%$, and $29 \%$ in the removal of COD, $\mathrm{NH}_{4}-\mathrm{N}$, and $\mathrm{PO}_{4}-\mathrm{P}$, respectively, have been achieved compared with fixed beds without vegetation [36]. However, polycultures are an attractive solution for domestic wastewaters even at temperatures as low as $8.9^{\circ} \mathrm{C}$ [37]. It has been shown that high organic loading rates and toxic substances supplied in CWs have been treated effectively, so this alternative has the potential to operate easily in countries without advanced technological capabilities [38].

The objective of this work was to evaluate the co-treatment of the liquid fraction of FVW using a combination of two methods for the reduction of pollutants (COD, TKN, Tot-P, TS, and TVS). This was accomplished by means of an anaerobic bioreactor system integrated into constructed wetlands in which were planted monocultures and polycultures of tropical ornamental plants with different OLR values. This study provides data on the design, construction, start-up, and operation of a hybridized ecological treatment system. 


\section{Materials and Methods}

Figure 1 shows the general sections of the two-stage methodology for the co-treatment of FVW.

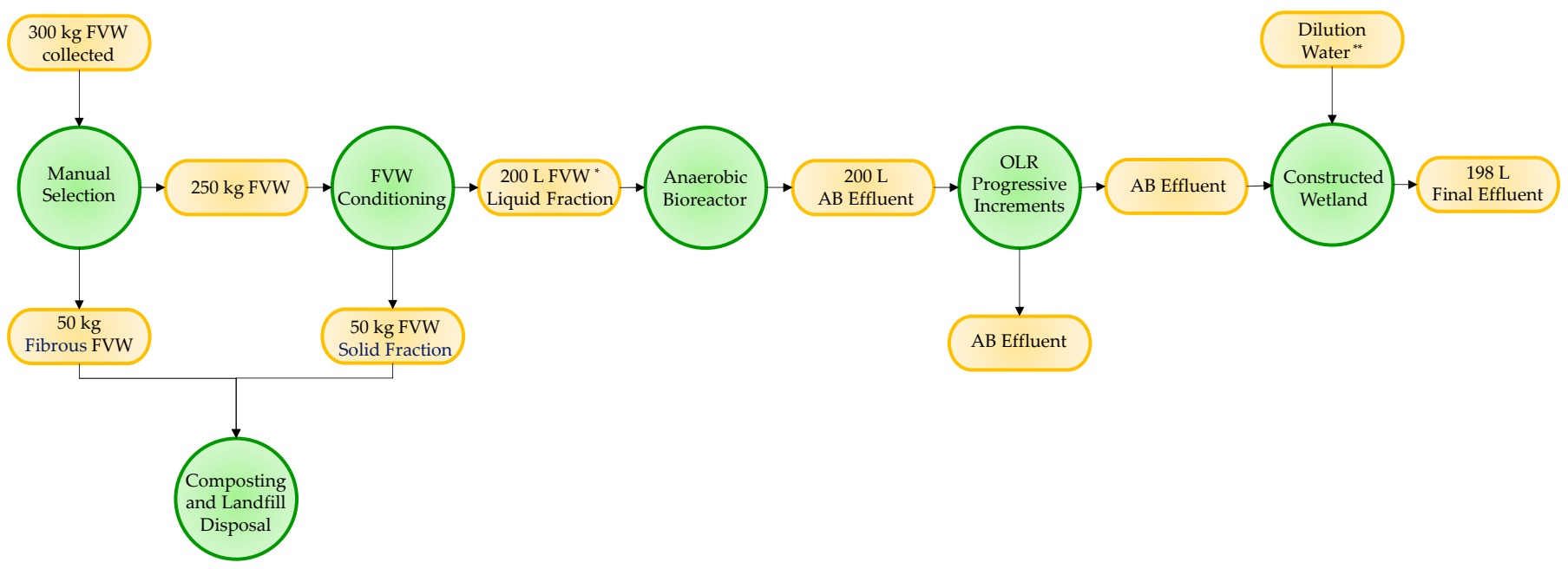

Figure 1. General sections of the hybrid methodology for the co-treatment of FVW. * From the fractions obtained by conditioning: $1 \mathrm{~kg}$ of FVW equals 77\% of FVW liquid fraction i.e., $1 \mathrm{~L}$ adding solubilization water (Alvarado-Lassman et al., 2016) [39]. ** See figure in Section 2.4 Hydraulic regimes and organic loading rates for the $\mathrm{CW}$.

Due to the liquid fraction from the FVW having a variable behavior, mainly in its concentration, caused by the dynamics of FVW generation and management in public markets of Mexico, we decided to evaluate its direct treatment through anaerobic digestion and by subsequently dosing the effluent pretreated by the AB (Stage 1) through stepwise concentrarion increments until the saturation conditions of the constructed wetlands (Stage 2) were found. In order to determine the behavior of the treatment system with different concentrations to ensure its effectiveness, we sought in each test to decrease the dilution of the contaminant components to replicate real-life practice.

\subsection{Study Site}

The experimental units were operated in a shaded greenhouse of the Plant for the Use of Organic Solid Waste at the Instituto Tecnológico de Orizaba, which is located at an altitude between 1200 and $2100 \mathrm{~m}$ and has a humid/semi-warm climate, high humidity $(\sim 99 \%)$, and abundant rainfall in the summer. The temperature ranges between 16 and $20{ }^{\circ} \mathrm{C}$, and the annual rainfall is in the range of 1500-2000 $\mathrm{mm}$.

\subsection{Substrate}

The FVW was collected from the transfer station of the Emiliano Zapata Municipal Market in the city of Orizaba, Veracruz, Mexico (126,719 inhabitants), where local suppliers preferably sell at retail price fruits and vegetables, which consist mainly of tomatoes, oranges, pineapples, onions, carrots, and other products in smaller proportions.

Initially, a physical pretreatment was done, and a manual selection was made from a total of $250 \mathrm{~kg}$ to eliminate the fibrous and lignocellulosic components that are not useful. Afterwards, a manual size reduction with blades was performed for subsequent shredding (dilution with processed water recovered in other treatments through anaerobic digestion reactors) using a VEYCO MCV 320 blade mill with a screw conveyor and a maximum capacity of $100 \mathrm{~kg} / \mathrm{h}$. Finally, the shredded FVW was centrifuged with a $2 \mathrm{~mm}$ mesh. This filtrate corresponds to the liquid fraction of the FVW ( $80 \%$ on average). The solid fraction remaining from the manual selection and conditioning was disposed of in a landfill 
and by composting. Some of the characteristics of the obtained substrate over the entire experimental period are listed in Table 1.

Table 1. Average composition of the FVW ${ }^{1}$.

\begin{tabular}{cc}
\hline Parameter & Mean Content \\
\hline COD $_{\mathrm{T}}(\mathrm{g} / \mathrm{L})$ & $44.0 \pm 2.4$ \\
$\mathrm{COD}_{\mathrm{S}}(\mathrm{g} / \mathrm{L})$ & $32.0 \pm 1.8$ \\
$\mathrm{TS}(\mathrm{g} / \mathrm{L})$ & $22.5 \pm 0.85$ \\
$\mathrm{TVS}(\mathrm{g} / \mathrm{L})$ & $17.33 \pm 0.72$ \\
Tot-P $(\mathrm{mg} / \mathrm{L})$ & $17.26 \pm 1.8$ \\
$\mathrm{TKN}(\mathrm{mg} / \mathrm{L})$ & $16.02 \pm 1.5$ \\
Temperature $\left({ }^{\circ} \mathrm{C}\right)$ & $24.0 \pm 1.2$ \\
$\mathrm{pH}$ & $3.81 \pm 0.3$ \\
\hline
\end{tabular}

${ }^{1}$ Each sample had two replications. Values are given as the mean \pm standard error $(n=24)$.

\subsection{Experimental Devices}

\subsubsection{Stage 1. Anaerobic Bioreactor}

A batch-fed pilot-scale (250 L) anaerobic bioreactor was operated with a working volume of $200 \mathrm{~L}$ to partially degrade complex organic matter. The AB was constructed of fiberglass coated with an anti-reflective paint, a wall thickness of $0.64 \mathrm{~cm}$, and a height of $1.04 \mathrm{~m}$. The AB was equipped with $5.08 \mathrm{~cm}$ (2 inch) PVC SCH 80 connections, valves, and pipes. A recirculation flow pump was also installed, enabling complete mixing. Twelve consecutive batch digestion tests of the FVW liquid fraction were performed under mesophilic conditions $\left(35 \pm 2{ }^{\circ} \mathrm{C}\right)$ at a neutral $\mathrm{pH}(7.0 \pm 0.2)$, whereas biogas production was not measured and complementation on nutrient removal was done at a later stage. These operational conditions were maintained for each consecutive batch. At start-up, the $\mathrm{AB}$ was inoculated proportionally with bovine rumen fresh grass-liquid fraction (3:7). The stabilization phase to the continuous operation phase lasted for 365 days prior to the implementation of the hybrid treatment system (data not shown). Therefore, the bacteria were already accustomed to this kind of substrate [30,39].

\subsubsection{Stage 2. Constructed Wetlands}

The following activities were conducted in this stage and were carried out over a continuous operating period of 12 months:

- $\quad$ CW start-up. As shown in Figure 1, eighteen high-density polyethylene cells ( $L=45$; $\mathrm{W}=20 ; \mathrm{H}=20 \mathrm{~cm}$ ) fed individually with a vertical subsurface flow and with a $\mathrm{TV}=30 \mathrm{~L}$ and a useful volume of $11 \mathrm{~L}$ were installed. In 9 cells, red volcanic gravel (RVG) with porous characteristics, a medium diameter $(3-5 \mathrm{~cm})$, and low hardness and density [40] was used as a fixed bed. Similarly, in the remaining cells, a mixture of RVG and pieces of corrugated polyethylene (PE) was used in equal parts. The CW was made up of all of the units, and it had a total treatment capacity of $198 \mathrm{~L}$.

- $\quad$ Plant establishment. Two tropical ornamental plant species (see Figure 2), i.e., Hippeastrum rutilum and Spathiphyllum wallisii, for both fixed beds (RVG and RVG + PE) were used to plant monocultures and polycultures with one and two specimens per species with a duplicate and a control cell without vegetation. The plant specimens were planted at a depth of $5 \mathrm{~cm}$. Initially, a period of adaptation of the plants to the new contamination conditions of 3 months in flood conditions with tap water was considered, where the sampling time was every 15 days as is explained below [41].

- Growth measurement. Plant biometry was performed over a period of twelve months (including the adaptation period). The sampling time was every 15 days during the entire study period, and measurements were taken directly from the plant in each cell. The measurements included leaf length $(\mathrm{L} \times \mathrm{W})$, leaf height $(\mathrm{H})$, and the number of shoots and deaths. These were performed similarly to those reported by Wentzell et al. (2016) [42] and according to the case of each of the species. 
- Microbiological evaluations. At the end of the experimental period, to verify the presence of microorganisms within the $\mathrm{CW}$ that contributed to the degradation of the nutrients dissolved in the substrate, random representative $10 \mathrm{~g}$ samples were extracted from the fixed bed (RVG and RVG $+\mathrm{PE}$ ) and the material that had adhered to the roots, and the samples were preserved in $90 \mathrm{~mL}$ of $0.25 \mathrm{M} \mathrm{KH}_{2} \mathrm{PO}_{4}$ solution. After homogenization $(\mathrm{t}=10 \mathrm{~min} ; 120 \mathrm{rpm})$ and storage in a refrigerator $\left(4^{\circ} \mathrm{C}\right)$, dilutions corresponding to $10^{-1}, 10^{-2}$, and $10^{-3}$ were inoculated with $100 \mu \mathrm{L}$ of Nutrient Agar (NA) in triplicate in petri dishes. After the incubation period $\left(T=30^{\circ} \mathrm{C} ; \mathrm{t}=72 \mathrm{~h}\right)$, based on the macroscopic morphological characteristics, the total number of different strains obtained from each sample (CFU) was estimated. From these strains, sowing was performed by streaking in the plate with the selective media ELMARC for nitrogenfixing bacteria (an intense red central point) and SRMS for phosphorus-solubilizing bacteria (a yellow halo).

- Statistical Analysis. Once the system had been fully evaluated, the data were subjected to statistical analysis to determine differences between $\mathrm{CW}$ configurations using a two-way ANOVA with (a) type of support (RVG and RVG + PE); (b) vegetation species (Spathiphyllum and Hippeastrum); and (c) type of crop (monoculture and polyculture), a significance level of $5 \%$, and the response variable $\% \mathrm{COD}_{\mathrm{Rem}}$ in Minitab version 16.1.0.

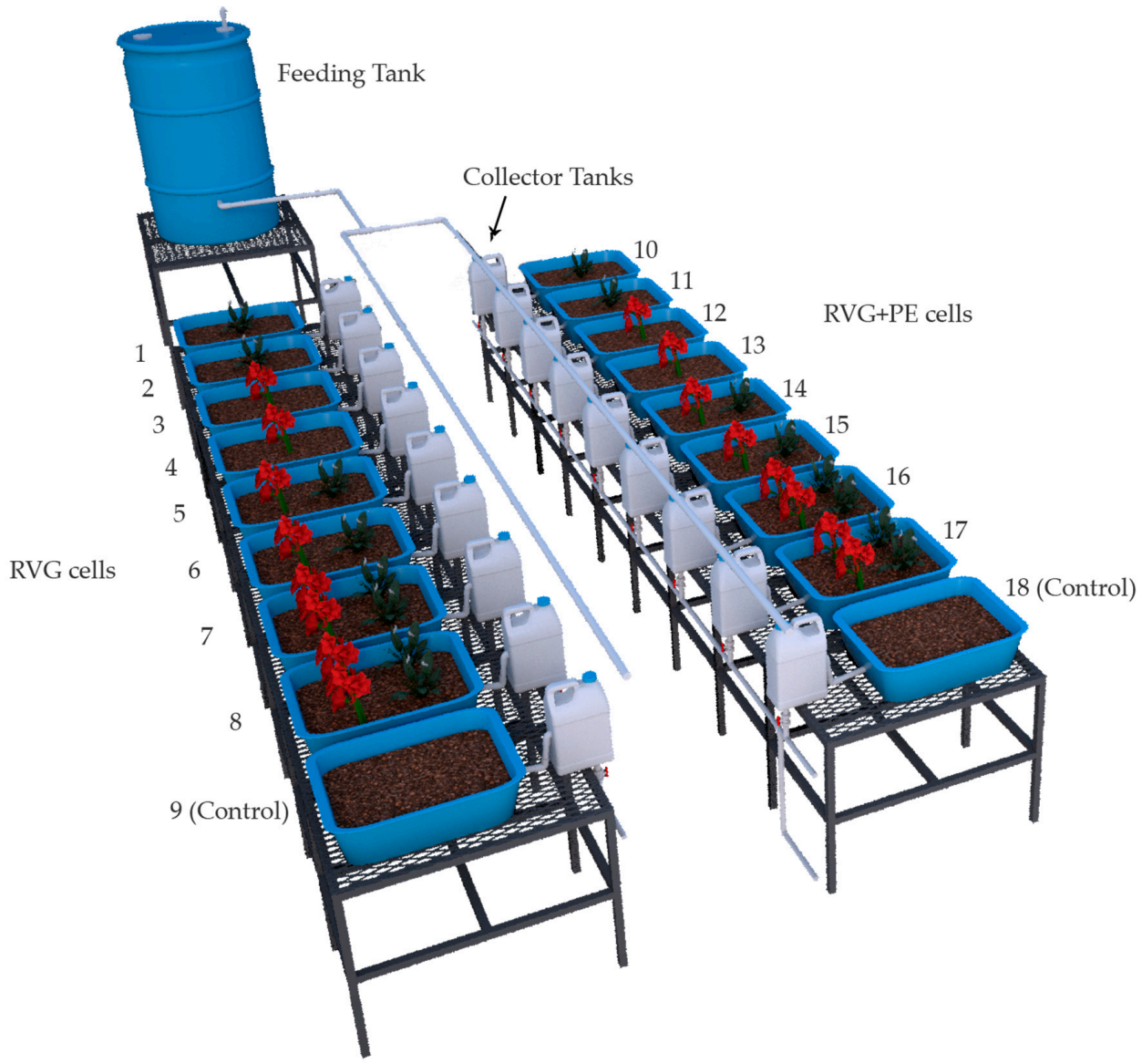

Figure 2. Monocultures and polycultures in the constructed wetland system.

\subsection{Hydraulic Regimes and Organic Loading Rates}

Stage 1: The AB was operated with the draw-and-fill method (batch-fed). A total of $200 \mathrm{~L}$ of the residues was removed, and $200 \mathrm{~L}$ of new substrate was fed once a day with the pump. Twelve batches were fed to the $\mathrm{AB}$ with an average OLR of $44 \mathrm{gCOD} / \mathrm{L}$ and a $\mathrm{HRT}=24 \mathrm{~h}$ by adjusting the $\mathrm{pH}$ with $\mathrm{NaOH}$. Samples of $250 \mathrm{~mL}$ at the inlet and the outlet 
for immediate analysis were taken. The resulting effluent was stored in a tank and used to feed the next stage.

Stage 2: Due to the high organic load, the AB effluent was added to the CW cells through the feeding tank by progressive concentration increments with no idle time. Each test corresponded to a new batch from the $\mathrm{AB}$ to ensure the conditioning and stabilization of the plant species under prolonged flood conditions.

The CW cells were fully flooded with partially digested effluent from the AB with a feeding flow of $2.54 \mathrm{~mL} / \mathrm{min}$ for $72 \mathrm{~h}$ without $\mathrm{pH}$ adjustments until $11 \mathrm{~L}$ of the treated effluent had left the experimental units in accordance with the steps explained below in Figure 3.

\begin{tabular}{|c|c|c|}
\hline $\begin{array}{l}\text { TEST } 1 \\
\text { REPETITIONS: } 2 \\
\text { RBA EFLUENT: } 4.5 \mathrm{~L} \\
\text { TAP WATER: } 193.5 \mathrm{~L} \\
\text { Inlet concentration: } 1 \mathrm{gCOD} / \mathrm{L} \\
\text { OLR: } 0.33 \text { gCOD/L·d }\end{array}$ & $\begin{array}{l}\text { TEST } 2 \\
\text { REPETITIONS: } 2 \\
\text { RBA EFLUENT: } 9 \mathrm{~L} \\
\text { TAP WATER: } 189 \mathrm{~L} \\
\text { Inlet concentration: } 2 \text { gCOD/L } \\
\text { OLR: } 0.67 \text { gCOD/L·d }\end{array}$ & $\begin{array}{l}\text { TEST } 3 \\
\text { REPETITIONS: } 2 \\
\text { RBA EFLUENT: } 13.5 \mathrm{~L} \\
\text { TAP WATER: } 184.5 \mathrm{~L} \\
\text { Inlet concentration: } 3 \mathrm{gCOD} / \mathrm{L} \\
\text { OLR: } 1 \text { gCOD/L·d }\end{array}$ \\
\hline \multicolumn{3}{|l|}{$\downarrow$} \\
\hline $\begin{array}{l}\text { TEST } 4 \\
\text { REPETITIONS: } 2 \\
\text { RBA EFLUENT: } 18 \mathrm{~L} \\
\text { TAP WATER: } 180 \mathrm{~L} \\
\text { Inlet concentration: } 4 \text { gCOD/L } \\
\text { OLR: } 1.33 \text { gCOD/L·d }\end{array}$ & $\begin{array}{l}\text { TEST } 5 \\
\text { REPETITIONS: } 2 \\
\text { RBA EFLUENT: } 22.5 \mathrm{~L} \\
\text { TAP WATER: } 175.5 \mathrm{~L} \\
\text { Inlet concentration: } 5 \mathrm{gCOD} / \mathrm{L} \\
\text { OLR: } 1.66 \mathrm{gCOD} / \mathrm{L} \cdot \mathrm{d}\end{array}$ & $\begin{array}{l}\text { TEST } 6 \\
\text { REPETITIONS: } 2 \\
\text { RBA EFLUENT: } 27 \mathrm{~L} \\
\text { TAP WATER: } 171 \mathrm{~L} \\
\text { Inlet concentration: } 6 \text { gCOD/L } \\
\text { OLR: } 2 \text { gCOD/L·d }\end{array}$ \\
\hline \multicolumn{3}{|l|}{$\sqrt{ }$} \\
\hline $\begin{array}{l}\text { TEST } 7 \\
\text { REPETITIONS: } 2 \\
\text { RBA EFLUENT: } 31.5 \mathrm{~L} \\
\text { TAP WATER: } 166.5 \mathrm{~L} \\
\text { Inlet concentration: } 7 \mathrm{gCOD} / \mathrm{L} \\
\text { OLR: } 2.33 \mathrm{gCOD} / \mathrm{L} \cdot \mathrm{d}\end{array}$ & $\begin{array}{l}\text { TEST } 8 \\
\text { REPETITIONS: } 2 \\
\text { RBA EFLUENT: } 36 \mathrm{~L} \\
\text { TAP WATER: } 162 \mathrm{~L} \\
\text { Inlet concentration: } 8 \mathrm{gCOD} / \mathrm{L} \\
\text { OLR: } 2.66 \mathrm{gCOD} / \mathrm{L} \cdot \mathrm{d}\end{array}$ & $\begin{array}{l}\text { TEST } 9 \\
\text { REPETITIONS: } 2 \\
\text { RBA EFLUENT: } 40.5 \mathrm{~L} \\
\text { TAP WATER: } 157.5 \mathrm{~L} \\
\text { Inlet concentration: } 9 \text { gCOD/L } \\
\text { OLR: } 3 \text { gCOD/L·d }\end{array}$ \\
\hline \multicolumn{3}{|l|}{$\sqrt{ }$} \\
\hline $\begin{array}{l}\text { TEST } 10 \\
\text { REPETITIONS: } 2 \\
\text { RBA EFLUENT: } 45 \mathrm{~L} \\
\text { TAP WATER: } 153 \mathrm{~L} \\
\text { Inlet concentration: } 10 \mathrm{gCOD} / \mathrm{L} \\
\text { OLR: } 3.33 \mathrm{gCOD} / \mathrm{L} \cdot \mathrm{d}\end{array}$ & \begin{tabular}{|l} 
TEST 11 \\
REPETITIONS: 2 \\
RBA EFLUENT: $49.5 \mathrm{~L}$ \\
TAP WATER: $148.5 \mathrm{~L}$ \\
Inlet concentration: 11 gCOD/L \\
OLR: 3.66 gCOD/L $\cdot \mathrm{d}$
\end{tabular} & $\begin{array}{l}\text { TEST } 12 \\
\text { REPETITIONS: } 2 \\
\text { RBA EFLUENT: } 54 \mathrm{~L} \\
\text { TAP WATER: } 144 \mathrm{~L} \\
\text { Inlet concentration: } 12 \mathrm{gCOD} / \mathrm{L} \\
\text { OLR: } 4 \text { gCOD/L·d }\end{array}$ \\
\hline
\end{tabular}

Figure 3. Hydraulic regimes and organic loading rates for the CW.

\subsection{Pollutant Measurement}

The system was monitored in the influent and in the effluent during all the tests, taking samples of $250 \mathrm{~mL}$ from each experimental device in both stages regularly to evaluate the removal percentages by measuring the $\mathrm{pH}$, total $\mathrm{COD}\left(\mathrm{COD}_{\mathrm{T}}\right)$, soluble $\mathrm{COD}$ (CODS), Total Solids (TS), and Total Volatile Solids (TVS). The $\mathrm{pH}$ was measured using an ORION 250 potentiometer. The $\mathrm{COD}_{\mathrm{T}}$ and $\mathrm{COD}_{\mathrm{S}}$ were determined by the colorimetric method with a HACH spectrophotometer at $620 \mathrm{~nm}$. The TS and TVS were determined by the gravimetric method using a Riossa oven and a Barnstead/Thermolyne muffle. In addition, for Stage 2, total nitrogen by the Kjeldahl method (TKN) and total phosphorus (Tot-P) were determined using the Standard Methods for the Examination of Water and Wastewater [43]. Additionally, a FVW liquid fraction analysis was performed for Salmonella spp., fecal coliforms, and Helminth eggs according to the NOM-004-SEMARNAT-2002, NMX-AA-042-SCFI-2015, and NMX-AA-113-SCFI-1999 standards, respectively, before and after treatment [44-46]. All the samples were immediately processed. 


\section{Results and Discussion}

The results obtained are presented below according to the two stages of the research methodology:

1. the anaerobic bioreactor; and

2. the constructed wetland.

\subsection{Stage 1: Anaerobic Bioreactor}

Removal of Organic Matter in the AB

Approximately $200 \mathrm{~L}(80 \%)$ of diluted FVW liquid fraction was obtained. It had an average concentration of $44 \mathrm{gCOD} / \mathrm{L}$, and the TS and TVS contents were about 22.5 and $17.33 \mathrm{~g} / \mathrm{L}$, respectively. This substrate was fed to the AB for all 12 tests (Figure 2). Despite the variability in their compositions, these wastes presented a relatively constant concentration and a high content of organic material congruent with that recorded by Alvarado-Lassman (2017) [39]. This justifies the physical pretreatment (shredding and filtration) of FVW. Note that this device had been stabilized previously.

Figure $4 \mathrm{a}$ presents the mean inlet and outlet concentrations for each of the two batches of the AB. It shows that, in spite of the variations in the inlet substrate, excellent results were achieved in most cases, and a pretreated effluent was generated with the removal of approximately $30 \mathrm{gCOD} / \mathrm{L}$. This was due to the consecutive days of work that led to the stabilization of the process. As shown in Figure $4 \mathrm{~b}$, between $55 \%$ and $60 \%$ of the total COD was removed $\left(\mathrm{COD}_{\mathrm{T} \text { Rem }}\right)$, and $45-60 \%$ of the soluble COD was removed $\left(\mathrm{COD}_{\mathrm{S} \text { Rem }}\right)$ according to the measurements that were made during the twelve tests. In the best case (Test 11 ), up to $65 \%$ of $\mathrm{COD}_{\mathrm{T} \text { Rem }}$ and $63 \%$ of $\mathrm{COD}_{\mathrm{S} \text { Rem }}$ were removed. On the contrary, the worst results were obtained in the third experimental test, and these results were caused by the increased concentration of the input.

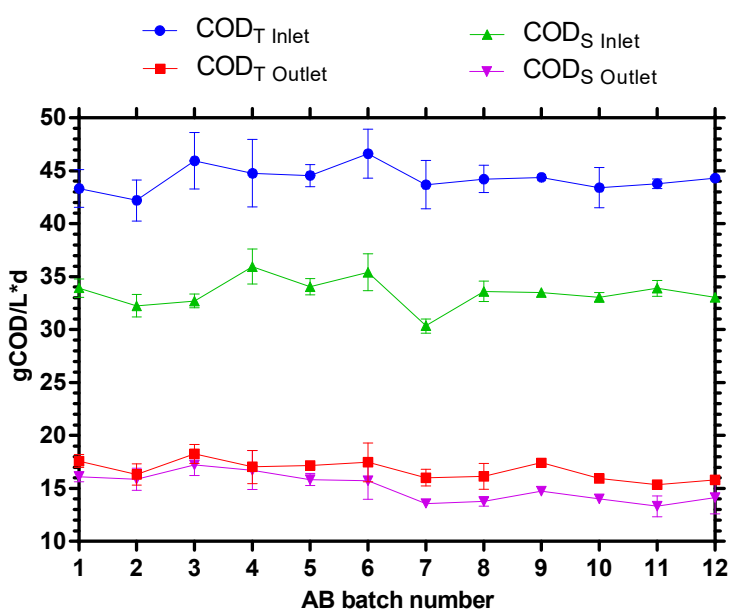

(a)

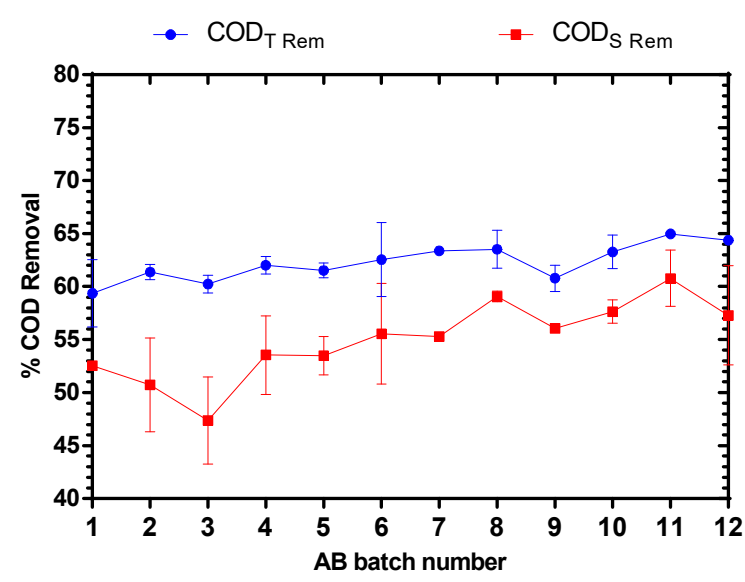

(b)

Figure 4. Testing of the AB: (a) inlet and outlet concentration; (b) percentage of COD removed.

The TS and TVS contents in the effluent were about 7.19 and $4.4 \mathrm{~g} / \mathrm{L}$, respectively, in Stage 1 . This indicates that about $68 \%$ of the TS and $86 \%$ of the vs. were removed in the $\mathrm{AB}$.

\subsection{Stage 2: Constructed Wetland}

\subsubsection{Environmental Conditions}

The average temperature during the tests after the adaptation period was $23 \pm 3.5^{\circ} \mathrm{C}$ under the shaded greenhouse conditions. The highest temperature recorded was $27^{\circ} \mathrm{C}$, and the minimum temperature during the early morning was $4{ }^{\circ} \mathrm{C}$. The average light intensity showed some variations due to the autumn-winter season with $300 \mu \mathrm{mol} / \mathrm{m}^{2} \mathrm{~s}$. 
With this, the temperature of the feed effluent was $25 \pm 1.5^{\circ} \mathrm{C}$, the temperature at the exit was $23 \pm 1.0^{\circ} \mathrm{C}$, and the humidity of the environment oscillated around $70 \pm 5 \%$.

\subsubsection{Removal of Organic Matter in the CW}

Using the pretreated effluent from the previous stage, the CW was fed to evaluate the difference between fixed beds (RVG and RVG + PE) and the monocultures and polycultures of each individual cell.

Thus, as shown in Figure 5, the COD values for both cases started at $1 \mathrm{gCOD} / \mathrm{L}$. After two repetitions, they increased to $2 \mathrm{gCOD} / \mathrm{L}$; thus, they increased successively according to Stage 2.

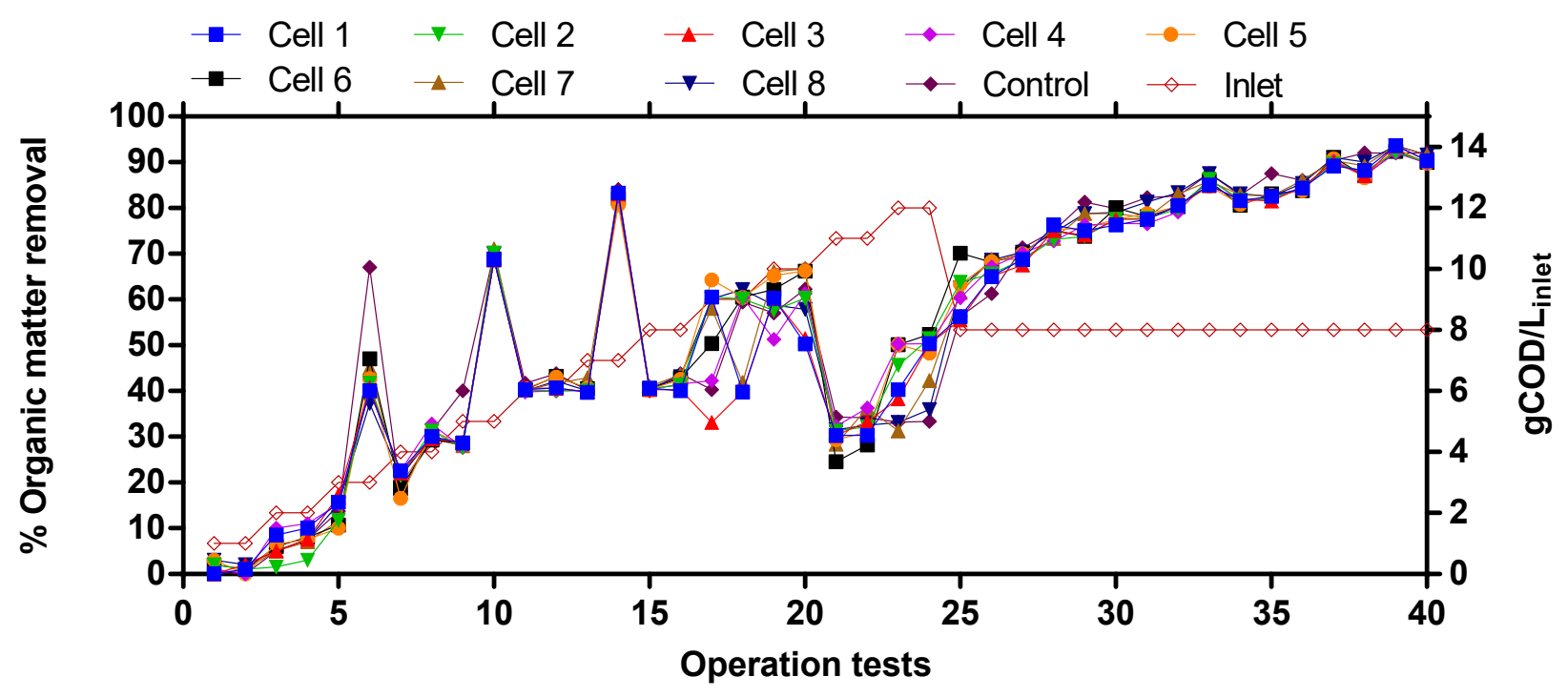

(a)

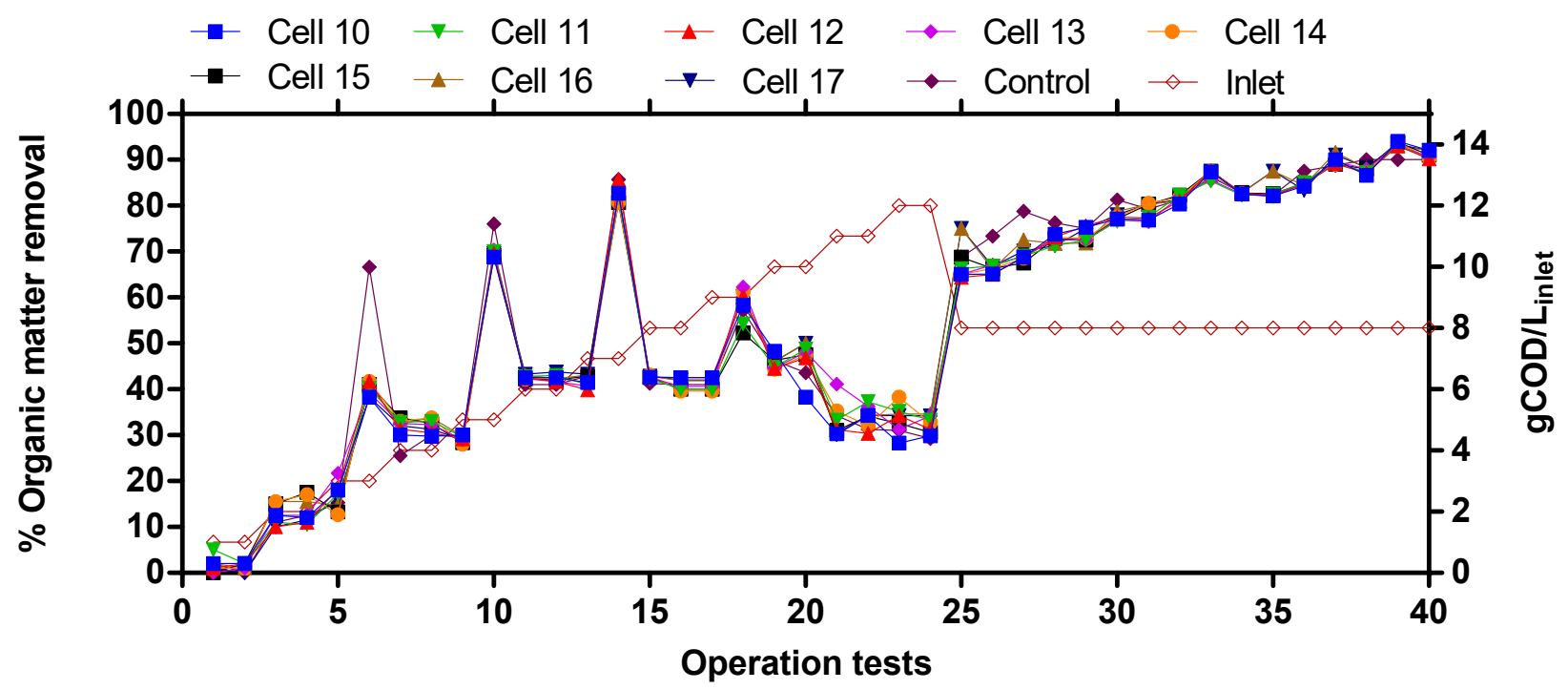

(b)

Figure 5. Average COD removal percentages by CW test: (a) RGV; (b) RGV + PE support.

Trials 6, 10, and 14 presented considerable alterations, i.e., doubling or tripling of the removal percentage $(60-85 \%)$, but this was due to the rain that occurred during the experiment. The rain filled the cells and diluted the input concentration, and this decreased the output concentration and caused an excessive amount of removal. This anomaly is 
justified, and it presented a slight decrease in the removal percentages of later tests. It can be inferred that the similarity between the yields of each cell was due to the filter material and its porosity, retaining the largest amount of suspended material and contributing to the fixation of matter for degradation by plant activity as shown in Figure $5 \mathrm{a}$ and as mentioned by Tejeda et al. (2017) [47]. In spite of this, the cells with a mixture of beds (see Figure 5b) created spaces without porous material, which resulted in a decrease in the contact surface area and, hence, impaired the retention of suspended material. Even so, the amount of material that was removed was not reduced significantly due to the action of the aerobic heterotrophic bacteria that occurred near the roots due to the availability of oxygen [48], generating an advantage in the design using PE to favor the space in which each species has to be able to develop a root with a greater degree of branching, according to Saraiva et al., (2019) [49], reaching values of $40 \%$ to $93.6 \%$ with outlet concentrations of 4.88 and $0.42 \mathrm{gCOD}_{\mathrm{T}} / \mathrm{L}$, respectively. However, in the operating range of 9 to $12 \mathrm{gCOD} / \mathrm{L}$ in the RVG, the degradation decreased considerably, i.e., up to $30 \%$, while for the case of RVG + PE, the performance of each cell was more susceptible to the variation in the OLR. From these results, the $8 \mathrm{gCOD} / \mathrm{L}$ load was again used, corresponding to an OLR of $2.66 \mathrm{gCOD} / \mathrm{Ld}$ and thereby exceeding $90 \%$ effectiveness irrespective of the configuration of the cell. This last operational condition was maintained until the completion of the 12-month period of monitoring of ornamental species. There was an increase in the percentage of organic material removal (COD) in both fixed beds due to the developing vegetation and the favorable conditions for the establishment and propagation of bacterial communities that together improve the CW [50].

In Stage 2, the TS and TVS contents were about 1.14 and $0.59 \mathrm{~g} / \mathrm{L}$, respectively, in the effluent of the CW. This indicates that about $78 \%$ and $75 \%$ of the TS and TVS, respectively, was removed. The best performances were obtained with $>75 \%$ removal of TS and TVS after 25 operational tests (see Figure 5) as shown in Figure 6.

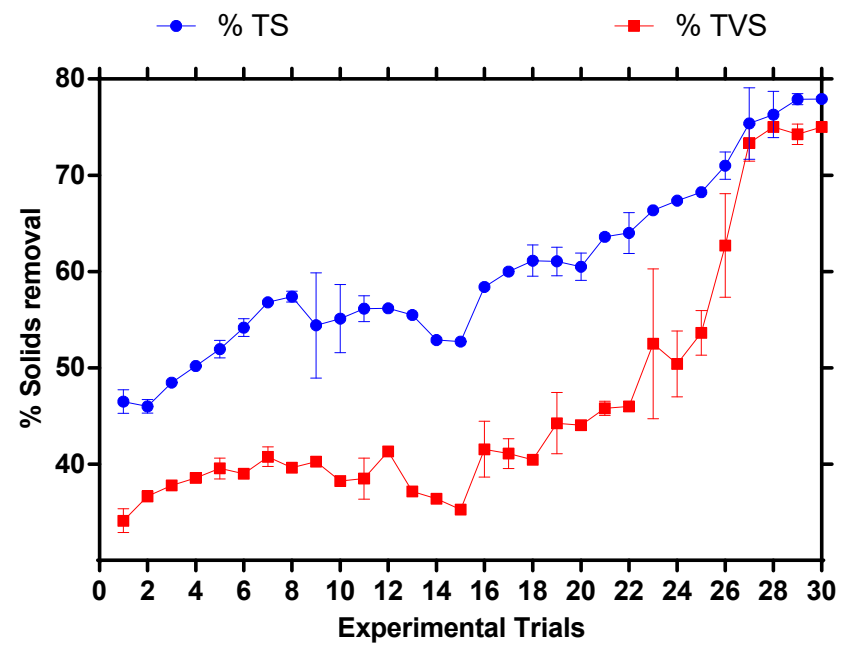

Figure 6. Solids removal by the CW.

The reason for the variation in removal percentages is the increase in activity and the development of the microbial community present and roots that transport oxygen to the sediment. It is worth noting that the implementation of the AB prior to the wetland treatment for solids removal is essential for long-term functionality [51].

Thanks to the reported configuration, similar removal percentages were achieved by other authors in parameters such as TOC (removal of up to 98\%) [52]. In this case, the adaptation of tropical ornamental species to wetland conditions may be feasible due to plant development even at low operating temperatures $\left(4^{\circ} \mathrm{C}\right.$ at dawn and $14{ }^{\circ} \mathrm{C}$ during the day), and, in accordance with this, the research by Pelissari et al. (2017) [53] is verified. The removal of pollutants at concentrations of 1-8 gCOD/L can be performed efficiently, rang- 
ing from $70 \%$ to $80 \%$ for COD and exceeding in some cases $90 \%$ for prolonged operational periods; thus, CW is complementary to the treatment systems that are frequently used.

\subsubsection{Nutrient Removal}

Considering an OLR of $2.66 \mathrm{gCOD} / \mathrm{L}^{*} \mathrm{~d}$ (from 25 to 40 operational tests, see Figure 5), the Tot-P removal (\%Tot- $\mathrm{P}_{\mathrm{Rem}}$ ) for the Hippeastrum rutilum monoculture reached values of $74.17 \%$ and $79.75 \%$ in RVG and RVG + PE, respectively; while for TKN removal (TKN Rem), these values were up to $75.34 \%$ and $82.95 \%$, respectively. In the case of Spathiphyllum wallisii, values of up to $80.15 \%$ Tot- $P_{\text {Rem }}$ and $82.72 \% \mathrm{TKN}_{\mathrm{Rem}}$ in RVG were obtained, while in the case of the mixture of beds values of $78 \%$ Tot- $P_{\text {Rem }}$ and $85 \% \mathrm{TKN} N_{\text {Rem }}$ were obtained. The polycultures with one specimen per species removed up to $77.78 \%$ of the phosphorus and $86.54 \%$ of the nitrogen in the cells with RVG, while, for the other case, the removals corresponded to $87.67 \%$ and $90.65 \%$. Finally, in the polycultures with two specimens per species (four plants per cell; i.e., two plants per species), the highest removal efficiency occurred in Cell 8 with an output concentration of $1.2 \mathrm{mgTot}-\mathrm{P} / \mathrm{L}$ (92.5\%) and Cell 7 with an output concentration of $1 \mathrm{mgTKN} / \mathrm{L}$ (93.84\%) in the first support evaluated. In contrast, the cells with RVG + PE only managed to reduce this content by values between $65 \%$ and $78 \%$ for both nutrients.

Therefore, this hybridization for the treatment of FVW presents favorable values and parameters that exceed the removal percentages recorded in the literature for domestic effluents and pesticides (a removal percentage of only $78 \%$ for COD) [54,55]. In comparison, this CW design removes more than $10 \mathrm{mg} / \mathrm{L}$ of NTK and Tot-P.

With respect to the type of cultivation, statistical differences were found in the COD removals for polycultures. This can be explained by the interaction that occurs between species when they are competing for nutrients and vegetation space and therefore increases their capacity for development, resulting in a direct increase in the removal of organic material. Similarly to the finding reported by He (2016), the species with the best results, as reflected in the plant growth, was the Hippeastrum species as it performs the processes of nitrification and denitrification effectively [56]. Despite this, all specimens managed to adapt to these conditions at the end of the experiment as described by Vymazal et al., (2014) [57]. However, the results for the Spathiphyllum species in the treatment of effluents with an abundance of organic content agree with those of some authors [50] with removal percentages higher than 90\%. Similarly, using RVG and the polycultures of both species, better results were obtained with an OLR of $2.66 \mathrm{gCOD} / \mathrm{L} \cdot \mathrm{d}$, exceeding $94.7 \%$ removal of COD.

\subsubsection{Microbiological Determinations}

An estimate is presented of the percentage of nitrogen-fixing and phosphorussolubilizing bacteria that may be involved in the purification process related to the type of crop (cell configuration) within the CW. According to Figure $7 \mathrm{a}$, up to $43 \%$ of nitrogen-fixing bacteria of the total CFUs were found in the nutrient agar (see Figure 7b), corresponding to Cell 2 with one specimen of Spathiphyllum with RVG. This proves that they were present in this type of system and, therefore, the metabolic degradation of these elements for nitrification, nitrate assimilation, and denitrification within the $\mathrm{CW}$ as described by Tan et al. (2021) [58]. Therefore, bacterial diversity is promoted [59], registering more than 30\% of phosphorus-solubilizing bacteria in Cell 3, where a specimen of Hippeastrum species was sown in RVG. For RVG + PE, the contents of nitrogen-fixing bacteria and phosphorussolubilizing bacteria were about $40 \%$ in Cell 16 (two specimens per species) and $28 \%$ in Cell 14 (one specimen per species), respectively. Therefore, an effluent with a considerable decrease in TKN and Tot-P was obtained. 


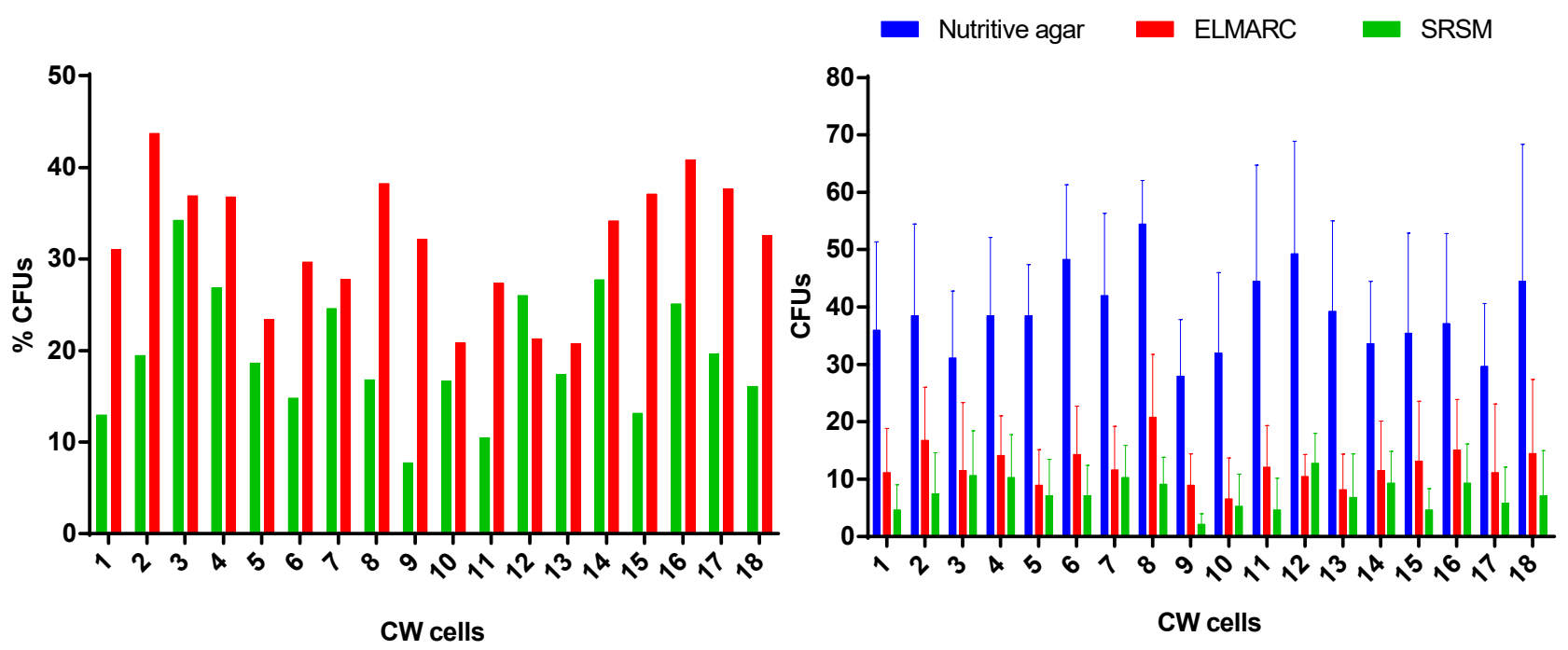

(a)

(b)

Figure 7. Percentage of CFUs inside the CW cells: (a) nitrogen-fixing bacteria and phosphorussolubilizing bacteria; (b) total count of bacterial CFUs.

Finally, in each stage, Salmonella spp. and fecal coliforms were determined. In both cases, $<3 \mathrm{NMP} / 100 \mathrm{~mL}$ and 0 Helminth eggs were found, which rules out the possibility of the presence of pathogenic microorganisms in this co-treatment system.

\subsubsection{Plant Development}

Figure 8 records the growth of the species in the CW cells for 12 months, i.e., from months $0-3$ for the adaptation period with tap water, from months $4-7$ for the stepwise concentration increments (see Figure 3), and from months 8-12 for the stable operating conditions with an OLR of $2.66 \mathrm{gCOD} / \mathrm{L} \cdot \mathrm{d}$, which shows the best elimination performances. Based on this, the Spathiphyllum species shows exponential growth, translating into a clear capacity for adaptation to flood conditions; however, there were considerable variations in its development beginning with the sixth month (see Figure 8a). This was due to the number of deaths (see Figure 8c) of these specimens. As for the Hippeastrum species (Figure 8b), the overlap between leaf height and leaf length was due to the morphology of the species, which is characterized by the leaves emerging from the bulb of the plant with the absence of a stem. It is important to highlight that, as the specimens of this species presented leaf deaths, the overall growth of the height, length, and width decreased and normalized three months later.

Figure 9 shows the flowering process of both ornamental species in the wetland cells.

The VWF treatment capacity of this novel, hybridized system surpasses that of other systems alone, such as photocatalytic reactors, the biofilm electrode reactor, anaerobic baffled reactors, and the UASB, that treat domestic and CW effluents using plants adapted and native to flood conditions $[54-56,60,61]$. The proposed system possesses operational advantages because the use of two processes was shown in other studies to raise the costs of operation and maintenance and to require long operating times, e.g., in the case of up-flow constructed wetlands or constructed wetland reactors [61,62]. 


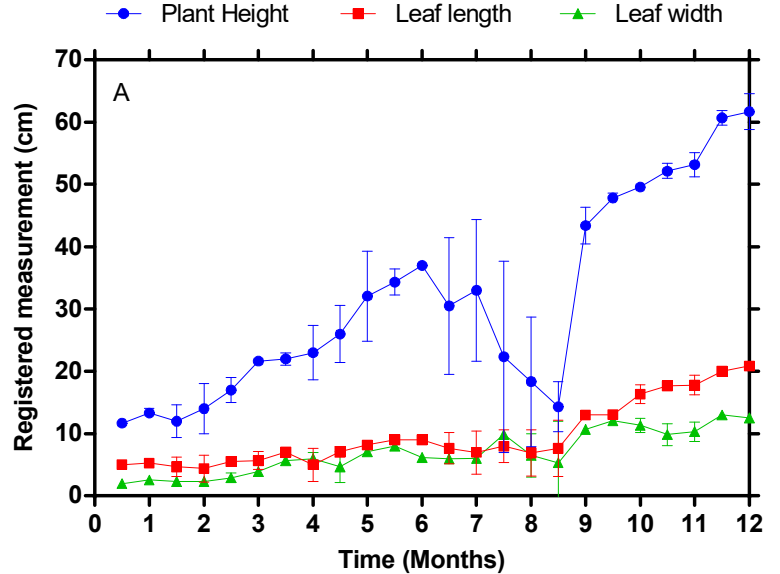

(a)

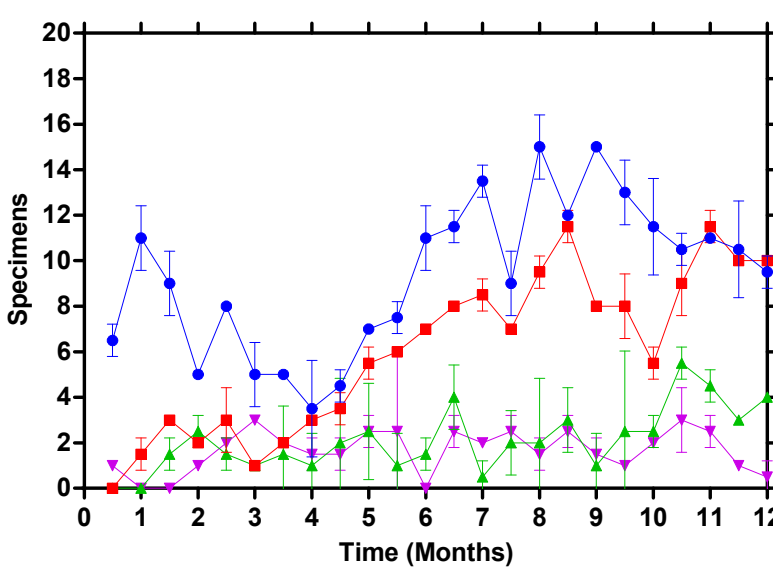

(c)

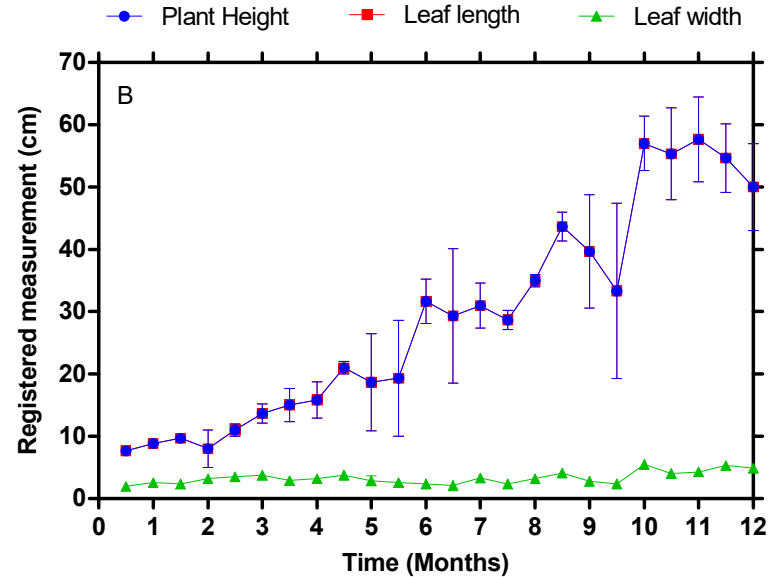

(b)

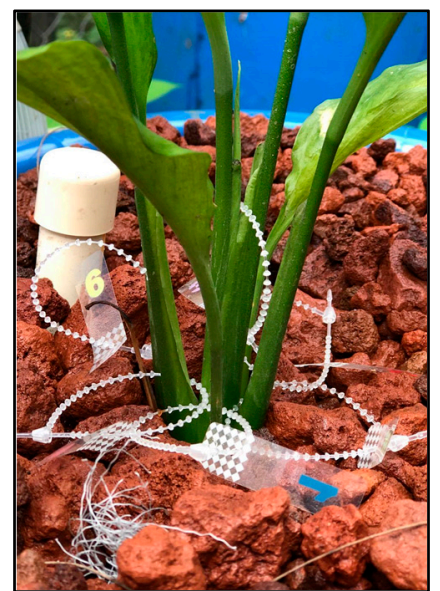

(d)

Figure 8. Plant development in the CW: (a) Spathiphyllum; (b) Hippeastrum; (c) deaths and buds; (d) ID monitoring.

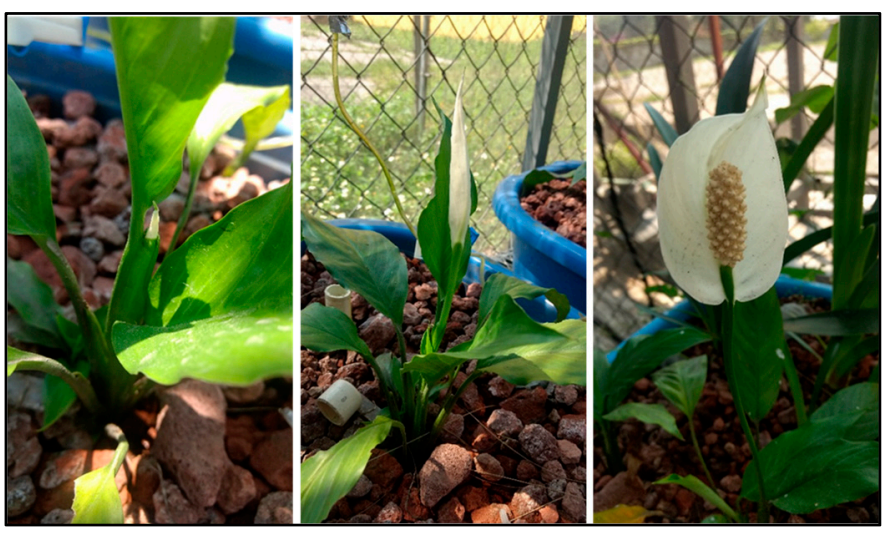

(a)

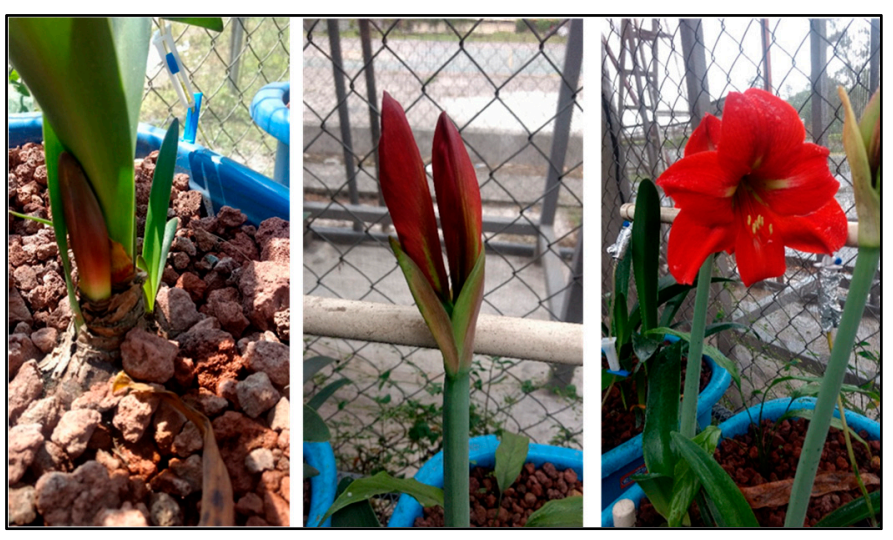

(b)

Figure 9. Ornamental plant flowering in the CW cells: (a) Spathiphyllum; (b) Hippeastrum. 


\section{Conclusions}

In this study, the co-treatment of FVW through the liquid fraction was found to be able to reduce the amount of pollutants using a system that combines a bioreactor and constructed wetlands.

The results show that the $\mathrm{AB}$ and $\mathrm{CW}$ degrade organic matter (COD, TS, and TVS) and nutrients (Tot-P and TKN) effectively, exceeding in some cases $90 \%$ removal of organic matter and nutrients with prolonged operation periods and ornamental polycultures of Hippeastrum spp. and Spathiphyllum wallisii. This treatment, based on the use of constructed wetlands, has proven to be an effective technology choice, increasing the nitrogen and phosphorus elimination capacity through the hybridization of the system. The use of RVG and PET provide a rooting zone and a reduction in pollutants by sequestering organic matter on the porous surfaces, accelerating plant development and spontaneous flowering in the off-season. It was found that the polyculture of ornamental plants is a variable that determines the effectiveness of nutrient removal, which makes it an effective solution for the co-treatment of FVW.

A single stage is not sufficient to carry out a complete waste treatment. The $A B$ provides a partial degradation of pollutants and a reduction in solids, which means that in the second stage there will be no clogging or saturation of pores and simple organic matter will be available for vegetation.

From the results of our study, it can be established that hybridization of these types of processes may become a viable option for the co-treatment of FVW and other substrates with a high content of organic material of food origin.

Author Contributions: Conceptualization, F.O.-G. and N.A.V.-C.; methodology, F.O.-G., A.A.-V. and L.C.S.-H.; software, L.C.S.-H.; validation, A.A.-L.; formal analysis, A.A.-L. and E.S.R.-M.; investigation, F.O.-G. and A.A.-V.; resources, N.A.V.-C. and A.A.-V.; writing-original draft preparation, F.O.-G. and A.A.-V.; writing-review and editing, A.A.-L. and E.S.R.-M.; visualization, E.S.R.-M. and L.C.S.-H.; supervision, A.A.-L.; project administration, N.A.V.-C.; funding acquisition, N.A.V.-C. All authors have read and agreed to the published version of the manuscript.

Funding: This work was carried out under the frame of project TecNM 5531.19-P, funded by Tecnológico Nacional de México.

Institutional Review Board Statement: Not Applicable.

Informed Consent Statement: Not Applicable.

Data Availability Statement: Not applicable.

Acknowledgments: Francisco Orduña-Gaytán acknowledges CONACYT for his Grant.

Conflicts of Interest: The authors declare no conflict of interest.

\section{References}

1. Pavi, S.; Kramer, L.E.; Gomes, L.P.; Miranda, L.A.S. Biogas production from co-digestion of organic fraction of municipal solid waste and fruit and vegetable waste. Bioresour. Technol. 2017, 228, 362-367. [CrossRef]

2. Chatterjee, B.; Mazumder, D. New approach of characterizing fruit and vegetable waste (FVW) to ascertain its biological stabilization via two-stage anaerobic digestion (AD). Biomass Bioenergy 2020, 139, 105594. [CrossRef]

3. Hecker, L.P. What Does It Take to Treat Municipal Wastewater in Developing Countries? An Econometric Analysis of Mexican Municipalities. Ph.D. Thesis, Brandenburg University of Technology, Brandenburg, Germany, 2018.

4. Garcia-Peña, E.I.; Parameswaran, P.; Kang, D.W.; Canul-Chan, M.; Krajmalnik-Brown, R. Anaerobic digestion and co-digestion processes of vegetable and fruit residues: Process and microbial ecology. Bioresour. Technol. 2011, 102, 9447-9455. [CrossRef]

5. Ji, C.; Kong, C.X.; Mei, Z.L.; Li, J. A review of the anaerobic digestion of fruit and vegetable waste. Appl. Biochem. Biotechnol. 2017, 183, 906-922. [CrossRef]

6. Mohd Basri, M.S.; Abdul Karim Shah, N.N.; Sulaiman, A.; Mohamed Amin Tawakkal, I.S.; Mohd Nor, M.Z.; Ariffin, S.H.; Mohd Salleh, F.S. Progress in the Valorization of Fruit and Vegetable Wastes: Active Packaging, Biocomposites, By-Products, and Innovative Technologies Used for Bioactive Compound Extraction. Polymers 2021, 13, 3503. [CrossRef]

7. Plazzotta, S.; Cottes, M.; Simeoni, P.; Manzocco, L. Evaluating the environmental and economic impact of fruit and vegetable waste valorisation: The lettuce waste study-case. J. Clean. Prod. 2020, 262, 121435. [CrossRef] 
8. Edwiges, T.; Frare, L.; Mayer, B.; Lins, L.; Triolo, J.M.; Flotats, X.; de Mendonça Costa, M.S.S. Influence of chemical composition on biochemical methane potential of fruit and vegetable waste. Waste Manag. 2018, 71, 618-625. [CrossRef]

9. CCA. Cuantificación de la Pérdida y el Desperdicio de Alimentos y Sus Efectos, Informe Técnico; Comisión Para la Cooperación Ambiental: Montreal, QC, Canada, 2019; p. 149.

10. Matobole, K.; Seodigeng, T.; Rutto, H. Ultrasonic Pre-treatment Investigation on Biogas Production of Biomethane of Fruit and Vegetable Waste. Chem. Eng. Trans. 2021, 86, 1471-1476.

11. Ganesh, K.S.; Sridhar, A.; Vishali, S. Utilization of fruit and vegetable waste to produce value-added products: Conventional utilization and emerging opportunities-A review. Chemosphere 2022, 287, 132221. [CrossRef]

12. US EPA. Basic Information about Landfill Gas by Landfill Methane Outreach Program (LMOP). Retrieved 1 December 2021. Available online: https:/ / www.epa.gov/lmop/basic-information-about-landfill-gas\#: \{\}:text=Instead\%20of\%20escaping\%20 into\%20the, smog\%20and\%20global\%20climate\%20change (accessed on 7 October 2021).

13. Levis, J.W.; Barlaz, M.A.; Themelis, N.J.; Ulloa, P. Assessment of the state of food waste treatment in the United States and Canada Waste Manag. 2010, 30, 1486-1494. [CrossRef]

14. Bouallagui, H.; Cheikh, R.B.; Marouani, L.; Hamdi, M. Mesophilic biogas production from fruit and vegetable waste in a tubular digester. Bioresour. Technol. 2003, 86, 85-89. [CrossRef]

15. Dalke, R.; Demro, D.; Khalid, Y.; Wu, H.; Urgun-Demirtas, M. Current status of anaerobic digestion of food waste in the United States. Renew. Sustain. Energy Rev. 2021, 151, 111554. [CrossRef]

16. US EPA. Environmental Benefits of Anaerobic Digestion (AD). Retrieved 1 August 2021. Available online: https://www.epa. gov/anaerobic-digestion/environmental-benefits-anaerobic-digestion-ad\#: :text=Reduce $\% 20 \mathrm{methane} \% 20 \mathrm{emissions} \% 20 \mathrm{from} \% 20$ manure,and\%20high\%20quality\%20fertilizer\%3B\%20and (accessed on 7 September 2021).

17. Misi, S.; Forster, C. Semi-continuous anaerobic co-digestion of agro-wastes. Environ. Technol. 2002, 23, 445-451. [CrossRef]

18. World Bank. Mexico: Conceptual Framework for a National Strategy on Food Loss and Waste. 2018. Internal Document. Available online: https:/ / wrap.org.uk/resources/report/conceptual-framework-national-strategy-food-loss-and-waste-mexico (accessed on 15 October 2021).

19. Arvanitoyannis, I.S.; Varzakas, T.H. Vegetable waste treatment: Comparison and critical presentation of methodologies. Crit. Rev. Food Sci. Nutr. 2008, 48, 205-247. [CrossRef]

20. Alvarado-Lassman, A.; Rustrián, E.; García-Alvarado, M.A.; Rodríguez-Jiménez, G.C.; Houbron, E. Brewery wastewater treatment using anaerobic inverse fluidized bed reactors. Bioresour. Technol. 2008, 99, 3009-3015. [CrossRef]

21. Beurskens, W.L.; Hekkenberg, M.; Vethman, P. Renewable Energy Projections as Published in the National Renewable Energy Action Plans of the European Member States. ECN-E-10-069; European Environment Agency: København, Denmark, $2011 ;$ p. e10069.

22. Christ, O.; Wilderer, P.A.; Angerhöfer, R.; Faulstich, M. Mathematical modeling of the hydrolysis of anaerobic processes. Water Sci. Technol. 2000, 41, 61-65. [CrossRef]

23. Park, C.; Lee, C.; Kim, S.; Chen, Y.; Chase, H.A. Upgrading of anaerobic digestion by incorporating two different hydrolysis processes. J. Biosci. Bioeng. 2005, 100, 164-167. [CrossRef]

24. Hernández, A. Ecological engineering for controlling water pollution in Latin America. Ecol. Dimens. Sustain. Soc. Econ. Dev. 2013, 64, 465-481.

25. Esposito, G.; Frunzo, L.; Panico, A.; Pirozzi, F. Modelling the effect of the OLR and OFMSW particle size on the performances of an anaerobic co-digestion reactor. Process Biochem. 2011, 46, 557-565. [CrossRef]

26. Di Maria, F.; Sordi, A.; Cirulli, G.; Gigliotti, G.; Massaccesi, L.; Cucina, M. Co-treatment of fruit and vegetable waste in sludge digesters. An analysis of the relationship among bio-methane generation, process stability and digestate phytotoxicity. Waste Manag. 2014, 34, 1603-1608.

27. Fonoll, X.; Astals, S.; Dosta, J.; Mata-Alvarez, J. Anaerobic co-digestion of sewage sludge and fruit wastes: Evaluation of the transitory states when the co-substrate is changed. Chem. Eng. J. 2015, 262, 1268-1274. [CrossRef]

28. Ganesh, R.; Torrijos, M.; Sousbie, P.; Lugardon, A.; Steyer, J.P.; Delgenes, J.P. Effect of increasing proportions of lignocellulosic cosubstrate on the single-phase and two-phase digestion of readily biodegradable substrate. Biomass Bioenergy 2015, 80, 243-251. [CrossRef]

29. Wang, X.; Li, Z.; Bai, X.; Zhou, X.; Cheng, S.; Gao, R.; Sun, J. Study on improving anaerobic co-digestion of cow manure and corn straw by fruit and vegetable waste: Methane production and microbial community in CSTR process. Bioresour. Technol. 2018, 249, 290-297. [CrossRef]

30. Alvarado-Lassman, A.; Sandoval-Ramos, A.; Flores-Altamirano, M.G.; Vallejo-Cantú, N.A.; Méndez-Contreras, J.M. Strategies for the Startup of Methanogenic Inverse Fluidized-Bed Reactors Using Colonized Particles. Water Environ. Res. 2010, 82, 387-391. [CrossRef]

31. Marín-Peña, O.; Alvarado-Lassman, A.; Vallejo-Cantú, N.A.; Juárez-Barojas, I.; Rodríguez-Jarquín, J.P.; Martínez-Sibaja, A. Electrical Conductivity for Monitoring the Expansion of the Support Material in an Anaerobic Biofilm Reactor. Processes 2020, 8 , 77. [CrossRef]

32. Rosas-Mendoza, E.S.; Méndez-Contreras, J.M.; Martínez-Sibaja, A.; Vallejo-Cantú, N.A.; Alvarado-Lassman, A. Anaerobic digestion of citrus industry effluents using an Anaerobic Hybrid Reactor. Clean Technol. Environ. Policy 2018, 20, 1387-1397. [CrossRef] 
33. Cheng, H.; Li, Y.; Kato, H.; Li, Y.Y. Enhancement of sustainable flux by optimizing filtration mode of a high-solid anaerobic membrane bioreactor during long-term continuous treatment of food waste. Water Res. 2020, 168, 115195. [CrossRef]

34. Inaba, T.; Aoyagi, T.; Hori, T.; Charfi, A.; Suh, C.; Lee, J.H.; Habe, H. Long-term acclimatization of sludge microbiome for treatment of high-strength organic solid waste in anaerobic membrane bioreactor. Biochem. Eng. J. 2020, 154, 107461. [CrossRef]

35. Khalid, A.; Arshad, M.; Anjum, M.; Mahmood, T.; Dawson, L. The anaerobic digestion of solid organic waste. Waste Manag. 2011, 31, 1737-1744. [CrossRef]

36. Sandoval, L.; Zurita, F.; Ángel-Coronel, D.; Andrés, O.; Adame-García, J.; Marín-Muñíz, J.L. Influence of a new ornamental species (Spathiphyllum blandum) on the removal of COD, nitrogen, phosphorus and fecal coliforms: A mesocosm wetland study with PET and tezontle substrates. Water Sci. Technol. 2020, 81, 961-970. [CrossRef]

37. Oon, Y.-L.; Ong, S.A.; Ho, L.N.; Wong, Y.S.; Dahalan, F.A.; Oon, Y.S.; Nordin, N. Role of macrophyte and effect of supplementary aeration in up-flow constructed wetland-microbial fuel cell for simultaneous wastewater treatment and energy recovery. Bioresour. Technol. 2017, 224, 265-275. [CrossRef] [PubMed]

38. Sehar, S.; Nasser, H.A.A. Wastewater treatment of food industries through constructed wetland: A review. Int. J. Environ. Sci. Technol. 2019, 16, 6453-6472. [CrossRef]

39. Alvarado-Lassman, A.; Méndez-Contreras, J.M.; Martínez-Sibaja, A.; Rosas-Mendoza, E.S.; Vallejo-Cantú, N.A. Biogas production from the mechanically pretreated, liquid fraction of sorted organic municipal solid wastes. Environ. Technol. 2017, 38, 1342-1350. [CrossRef] [PubMed]

40. Zurita, F.; White, J.R. Comparative study of three two-stage hybrid ecological wastewater treatment systems for producing high nutrient, reclaimed water for irrigation reuse in developing countries. Water 2014, 6, 213-228. [CrossRef]

41. Luo, F.L.; Huang, L.; Lei, T.; Xue, W.; Li, H.L.; Yu, F.H.; Cornelissen, J.H. Responsiveness of performance and morphological traits to experimental submergence predicts field distribution pattern of wetland plants. J. Veg. Sci. 2016, 27, 340-351. [CrossRef]

42. Wentzell, B.M.; Boylen, C.W.; Nierzwicki-Bauer, S.A. Wetland ecosystem comparison using a suite of plant assessment measures. Ecol. Indic. 2016, 67, 283-291. [CrossRef]

43. Federation, Water Environmental; APH Association. Standard Methods for the Examination of Water and Wastewater; American Public Health Association (APHA): Washington, DC, USA, 2005.

44. D.O.F. NOM-004-SEMARNAT-2002, N.O.M. Protección Ambiental.-Lodos y Biosólidos.-Especificaciones y Límites Máximos Permisibles de Contaminantes para su Aprovechamiento y Disposición Final. Diario Oficial de la Federación, viernes 15 de agosto del 2003. Available online: http:/ / dof.gob.mx/nota_detalle.php?codigo=736434\&fecha=18/02/2002 (accessed on 15 January 2020).

45. D.O.F. NMX-AA-042-SCFI-2015, N.M., Determinación del Número más Probable (NMP) de coliformes totales, coliformes fecales (termotolerantes) y Escherichia coli. D.F., México. 2015. Available online: http:/ /dof.gob.mx/nota_detalle.php?codigo=736434 \&fecha=18/02/2002; https:/ / www.gob.mx/cms/uploads/attachment/file/166147/nmx-aa-042-scfi-2015.pdf (accessed on 15 January 2020).

46. D.O.F. NMX-AA-113-SCFI-1999. Analysis of Water-Determination of Helminth Eggs-Test Method. Mexico 1999. Available online: https://www.gob.mx/cms/uploads/attachment/file/166809/NMX-AA-113-SCFI-2012.pdf (accessed on 15 January 2020).

47. Tejeda, A.; Torres-Bojorges, Á.X.; Zurita, F. Carbamazepine removal in three pilot-scale hybrid wetlands planted with ornamental species. Ecol. Eng. 2017, 98, 410-417. [CrossRef]

48. Aguirre, P. Mecanismos de eliminación de la materia orgánica y de los nutrientes en humedales construidos de flujo subsuperficial. In Nuevos Criterios Para el Diseño y Operación de Humedales Construidos; CPET: Barcelona, Spain, 2004; pp. 17-30.

49. Saraiva, C.B.; Matos, A.T.; Matos, M.P.D. Extraction capacity of grasses grown in constructed wetland systems using different arrangements and substrates. Engenharia Agrícola 2019, 39, 668-675. [CrossRef]

50. Sandoval-Herazo, L.C.; Alvarado-Lassman, A.; Marín-Muñiz, J.L.; Méndez-Contreras, J.M.; Zamora-Castro, S.A. Effects of the use of ornamental plants and different substrates in the removal of wastewater pollutants through microcosms of constructed wetlands. Sustainability 2018, 10, 1594. [CrossRef]

51. Hunt, P.; Poach, M. State of the art for animal wastewater treatment in constructed wetlands. Water Sci. Technol. 2001, 44, 19-25. [CrossRef]

52. Melián, J.H.; Méndez, A.O.; Arana, J.; Díaz, O.G.; Rendón, E.T. Degradation and detoxification of formalin wastewater with aerated biological filters and wetland reactors. Process Biochem. 2008, 43, 1432-1435. [CrossRef]

53. Pelissari, C.; Ávila, C.; Trein, C.M.; García, J.; de Armas, R.D.; Sezerino, P.H. Nitrogen transforming bacteria within a full-scale partially saturated vertical subsurface flow constructed wetland treating urban wastewater. Sci. Total Environ. 2017, 574, 390-399. [CrossRef] [PubMed]

54. Araña, J.; i Cabo, C.G.; Rodríguez, C.F.; Melián, J.H.; Méndez, J.O.; Rodríguez, J.D.; Peña, J.P. Combining TiO Th $_{2}$ photocatalysis and wetland reactors for the efficient treatment of pesticides. Chemosphere 2008, 71, 788-794. [CrossRef] [PubMed]

55. Singh, S.; Haberl, R.; Moog, O.; Shrestha, R.R.; Shrestha, P.; Shrestha, R. Performance of an anaerobic baffled reactor and hybrid constructed wetland treating high-strength wastewater in Nepal-A model for DEWATS. Ecol. Eng. 2009, 35, 654-660. [CrossRef]

56. He, Y.; Wang, Y.; Song, X. High-effective denitrification of low $\mathrm{C} / \mathrm{N}$ wastewater by combined constructed wetland and biofilmelectrode reactor (CW-BER). Bioresour. Technol. 2016, 203, 245-251. [CrossRef]

57. Vymazal, J. Constructed wetlands for treatment of industrial wastewaters: A review. Ecol. Eng. 2014, 73, 724-751. [CrossRef] 
58. Tan, X.; Yang, Y.L.; Liu, Y.W.; Li, X.; Zhu, W.B. Quantitative ecology associations between heterotrophic nitrification-aerobic denitrification, nitrogen-metabolism genes, and key bacteria in a tidal flow constructed wetland. Bioresour. Technol. 2021, 337, 125449. [CrossRef]

59. Li, X.; Li, Y.; Lv, D.; Li, Y.; Wu, J. Nitrogen and phosphorus removal performance and bacterial communities in a multi-stage surface flow constructed wetland treating rural domestic sewage. Sci. Total Environ. 2020, 709, 136235. [CrossRef]

60. Lin, Y.; Yin, J.; Wang, J.; Tian, W. Performance and microbial community in hybrid anaerobic baffled reactor-constructed wetland for nitrobenzene wastewater. Bioresour. Technol. 2012, 118, 128-135. [CrossRef]

61. Saeed, T.; Afrin, R.; Al Muyeed, A.; Sun, G. Treatment of tannery wastewater in a pilot-scale hybrid constructed wetland system in Bangladesh. Chemosphere 2012, 88, 1065-1073. [CrossRef]

62. Ong, S.-A.; Uchiyama, K.; Inadama, D.; Ishida, Y.; Yamagiwa, K. Performance evaluation of laboratory scale up-flow constructed wetlands with different designs and emergent plants. Bioresour. Technol. 2010, 101, 7239-7244. [CrossRef] [PubMed] 